\title{
Minutes of the Eleventh Annual Meeting, 1982
}

The Eleventh Annual Meeting was held in London from 6 to 8 July, 1982 under the Presidency of Professor Kenneth Rawnsley.

\section{SCIENTIFIC MEETINGS}

The Scientific Meetings were held at the Royal Society of Medicine on 6, 7 and 8 July. The Joint Meeting with the British Association of Psychopharmacology was held at The Royal Society on 8 and 9 July.

Tuesday 6 July: Morning Session A

Dynamic psychiatry and clinical science-Professor $\mathbf{R}$. Cawley

Anorexia Nervosa

Delayed puberty due to anorexia nervosa-Professor Gerald Russell

Self-induced vomiting and bulimia nervosa: A communitybased survey-Dr Christopher Fairburn

A treatment trial of individual and family therapy in anorexia nervosa-Dr. Alyson Hall

\section{Morning Sexsion B}

Miscellaneous Papers

Split brain; split mind?-Dr Gareth Jones

Central processing and sensory perception in schizophrenia-Dr Malcolm Weller

Drug induced psychiatric disorder-Dr K. Davison

Neuropeptide changes in the temporal lobe in schizophrenia-Dr T. J. Crow

Plasmophoresis in schizophrenia-Professor S. C. Schultz

\section{Afternoon Seacion A}

The Chronic Patient

Old and new chronic patients-Dr Douglas Bennett

Rehabilitation: St Wulstan's fight for survival-Dr Roger Morgan

Do depot neuroleptics protect against the development of tardive dyskinesia?-Professor Solomon Goldberg

Positron emission tomography in psychotic epileptic patients-Dr Michael Trimble

Aftermoon Sescion B

Dementia-What Happens in the Patient's Brain and in the Patient's Home

Is Alzheimer's Disease part of a wider spectrum?-Dr M. N. Rosser

Genetics, ageing and dementia-Dr Alan Wright

A study of the supporters of confused elderly people at home: Medical and sociological aspects-Miss Enid Levin, Dr N. Graham, Dr Gillian Waldron
Wednesday 7 Juby

a-Adrenoceptors in depression-Dr S. Checkley

Validity of diagnostic rating scales in affective disordersDr James Mullaney

Treating compulsive gamblers-Dr David Greenberg

Thureday 8 July: Morning Sesdion A

Psychiatric History: Old and New

The development of the concept of functional disorders-Dr Michael Trimble

Genius and madness-Professor Neil Kessel

Male infibulation-Dr Denis Leigh

Hysteria-Dr Lindsay Hurst

Psycho politics: some limitations and further prospects- $-\mathrm{Mr}$ Peter Sedgwick

\section{Morning Session B}

Free Communications

Current knowledge of tricyclic antidepressant response indicators-Professor S. C. Goldberg

Dexamethasone suppression test in depression-Dr M.T. Abou-Saleh

CT scan study in schizophrenia in adolescence-Professor S. C. Schultz

The use of testosterone in the treatment of women with low libido-Dr J. M. Kellett

Changes in behaviour and in membrane bound enzymes following the chronic administration of alcohol to the rat-Miss Bernadette Keane and Professor B.E. Leonard

Benzodiazepine-Opiate antagonist interactions and reward processes: implications for drug dependency-Dr S. J. Cooper

Novel cognitive tests for the detection of brain damage in alcoholism-Dr R. J. Draper

Alcohol and human state-dependent learning-Dr G. Lowe

Examining the dopamine hypothesis of schizophrenia and of mania using the prolactin response to anti-psychotic drug treatment-Dr Trevor Silverstone

Alaproclate-An open-label study in depressive illness-Dr S. J. Frost, Professor D. Eccleston, Dr F. Hassanyeh and Dr Elizabeth F. Marshall

\section{Afternoon Sescion A}

Trainees' Research Papers

Measurement of reaction time following minor head injury-Dr G. MacFlynn

AEG and CAT scan changes in patients with affective disorders-Dr Hilary M. Standish-Barry 
Platelet alpha-2-adrenoceptors and maternity blues-Dr A Metz

Puerperal mental illness: A comparison with non-puerperal controls-Dr C. Katona

Prevalence of alcohol dependence in long-term prisonersDr H. Harbinson

Personality sub-group in a population of alcoholic patients-Dr D. Kingdon

Aggressive behaviour in a psychiatric observation wardDr S. Cooper

Mortality of the mentally handicapped: A 50-year surveyDr G. Carter

The role of surveys in the care of mentally handicapped patients-Dr Valerie Hughes

Stability of marriage between psychiatric patients- Dr J. Shanks

Psychological well-being in nurses in different clinical settings-Dr Martin Livingstone

What do psychiatrists understand by formulation-Dr Julie Hollyman

\section{Afternoon Session B}

Psychopharmacology and Sexual Disorders

(i) Sex in the Laboratory

Catecholamines and control of sexual behaviour-Dr B. J. Everitt

Effects of drugs on sexual behaviour in animals-Professor G. L. Gessa

SHT and sexual behaviour-Dr Sandra File

Sex hormones and the brain-Dr Hans Kopera

(ii) Sex in the Community

Sex counselling-Dr Patricia Gillan

Drug treatment of sexual offenders-Dr C. J. Mugglestone

Cholinergic and adrenergic mechanisms-Dr Alan Riley

Sexual dysfunction and prescribed psychotropic drugs- $-\mathrm{Dr}$ J. M. H. Rees

Friday 9 July

Drug Addiction, Alcoholism and Brain Damage

The mortality of alcoholism-Dr A. M. Adelstein

Genes and environment in alcoholism-Dr R. M. Murray

Pharmacogenetics of alcohol and its CNS effects-Professor P. Propping

NMR studies in alcoholism-Dr I. A. M. Glen

The reversibility of CT scan changes in alcoholism-Dr Maria Ron

Behavioural and biochemical effects of chronic amphetamine treatment in the vervet monkey-Dr R. M. Ridley

Long-term effects of benzodiazepines-Professor M.H. Lader

CAT scan and psychometry in long-term high-dose heroin addicts-Dr John Strang

Drinking histories from psychiatric patients: Are they accurate?-Dr M. W. Bernadt

Subcellular consequences of alcoholism-Dr T. J. Peters

The role of synaptic membrane lipids in the development of ethanol tolerance and dependence-Dr G. John

Tetrahydroisoquinolines and alcohol dependence-Miss Angela Clow

Tetrahydroisoquinolines in alcohol withdrawal-A correlate of craving?-Miss A. Topham

$\beta$-Carbolines and tryptolines in addiction-Dr R.B. Holman

Factors underlying tardive dyskinesia-Professor R.M. Hamer

\section{Other Sessions}

The Psychotherapy Section met on 6 July when Dr J. Roberts read a paper entitled 'Leadership Problems and the Psychopathology of Leaders in the Therapeutic Communities'.

\section{Distinguished Guest Lecture}

Professor Max Hamilton presented a paper entitled 'The Proper Study of Mankind' on 7 July.

\section{BUSINESS MEETING}

The Business Meeting was held on Wednesday 7 July 1982.

\section{Minutes}

The Minutes of the previous meeting held in London from 7 to 9 July 1981, having been published in the Bulletin (December 1981, pp. 228-39) were approved and signed as a correct record.

\section{Obituary}

The REgISTRAR announced with regret the names of those members who had died since the last College meeting.

\section{Annual Report of Council and the Registrar's} Supplementary Report

The Annual Report of Council had been circulated with the papers for the Meeting and Propessor Tmbury presented the following report of additional matters which had occurred.

'The Annual Report for 1982, which has been sent to all members, contains information about the work of the College Council, the Court of Electors, Standing and Special Committees, and the Divisions, Sections and Groups.

'Since the report was written there were meetings of the Court of Electors and the Council on 14 and 15 June, and the Executive and Finance Committee met on 11 June.

'The Court of Electors approved the results of the recent Membership Examination: 136 of the 298 candidates were successful-a pass rate of 46 per cent.

'The Court agreed that resulting from the publication of DHSS Circular HC(82)10 the College would be represented on Appointment Committees for Senior Registrars in 
England and Wales by the Regional Adviser or by an appropriate specialist nominated by him. This Circular also refers to proleptic appointments and the Court wish me to bring this to the attention of all members. The relevant paragraph reads:

Because the role of an Appointments Committee is to recommend the candidate or candidates they consider suitable for the post, it is not appropriate for them to recommend a candidate who is not yet suitably qualified but who would become so after undertaking further training. They may, however, advise that a particular candidate who is at present qualified for the post would nonetheless benefit from particular further training before taking up his duties.

'The Mental Health (Amendment) Bill continues to occupy the time and attention of College Officers and of Professor Bluglass and the members of the Public Policy Committee Working Party dealing with this matter. The Special Standing Committee of the House of Commons completed its work last week and we still expect that the Bill will complete its progress through Parliament by the end of this session.

'A Discussion Paper on the work of the Court of Protection and Guidelines for the use of doctors involved in certifying incapacity were approved by Council and will be published shortly.

'Comments on the Government's Response to the Report of the Social Services Committee on Medical Education (The Short Report) have also been approved by Council and have been forwarded to the DHSS.

'Council gave preliminary consideration to possible revision of the Bye-laws relating to the procedure for elections, the duration of office of members of Council and certain other committees and the introduction of a new form of Associate status for colleagues from other branches of medicine and other professions. A discussion paper on this topic will be circulated to the Divisions and Sections in the near future. I anticipate that any changes recommended by Council will be brought to the Annual Meeting in July 1983.

'Council suggested that the Bulletin should in future carry a monthly obituary list and that the Editor should, at his discretion, publish obituaries of distinguished College members.

'Council supported the request of the Mental Deficiency Section that its name be changed to the Specialist Section for the Psychiatry of Mental Handicap. Our Bye-laws, however, require this change to be approved by an Annual Meeting, which must receive twenty-eight days' notice of such a motion. This matter will therefore be brought to the Annual Meeting next year.

I would like to draw your attention to references made in the Annual Report to the contribution made to the College by two retiring office bearers. Dr Sasi Mahapatra has completed three years as a Sub-Dean, and Dr Tom Bewley has completed five years as Dean. We are all deeply grateful to them for their devotion to the work of the College. The ballot which has just been held has resulted in the election of Dr J. L. T. Birley as Dean and Dr Sheila Mann, Professor Seager and Dr Schapira, as Sub-Deans.

'Finally, we are extremely grateful to all the College staff for their hard work during the past year and for the arrangements which they have made for this Annual Meeting.'

\section{Annual Report of the Treasurer, 1981-82 Accounts for the year ended 31 December 1981}

DR C. M. B. PARE, Treasurer, introduced the Annual Accounts.

The College accounts for the year ended 31 December 1981 are given on pages 228 to 232 . They reveal a revenue surplus of $£ 30,090$ (compared with a surplus of $£ 114,397$ in 1980), which brings the accumulated 'capital' of the General and Appeal Fund to $£ 1,397,711$ after the appropriation of $£ 50,000$, to establish a College Development Fund as proposed in my report last year.

This year has seen the beginning of a period of consolidation; the capital expenditure upon the building, its furnishing and fittings has been less than half that of 1980 . Only restoration of the ground floor reception rooms and the repainting of the College exterior remains to be completed in the current year and no further major works are envisaged. For these reasons, and because the rate of inflation is reducing, I am not recommending to the Annual General Meeting any further increase in subscriptions this year.

This means that the College will not have a sufficient surplus next year to finance the expansion of research and educational activities. This, of course, is essential if we are to fulfil our leading role in British and world psychiatry. The ECT project, of which the College can be proud, was funded by the DHSS and cost about $£ 95,000$. We cannot always look to the DHSS to fund such investigations. It will be necessary to make a further appeal, for research and educational projects.

However, before embarking on a public appeal, it is vital to demonstrate to potential benefactors that members consider such projects to be important. The best way of doing this is by contributing ourselves as much as we can reasonably afford and the President will shortly be writing asking you to make and sign covenants to this effect.

Finally, may I thank all those members who pay their subscriptions by Direct Debit: 78 per cent of members now use this method which simplifies office work and so cuts the costs to the College. 
Appointments of Auditors

Messrs. Ernst and Whinney were re-appointed as the College Auditors for 1982-83. Proposed by Professor R. Bluglass, seconded by Professor C. P. Seager and carried nem con.

\section{Complimentary Motions}

The President thanked Mr and Mrs Brooks, the resident caretaker and housekeeper for their excellent service to the College and wished them well in their retirement.

\section{Presentation of Prizes}

The Gaskell Medal and Prize was presented to Dr J. M. Bird, Maudsley Hospital, London.

The Research Prize and Bronze Medal was awarded to Dr G. Stein, Cane Hill Hospital and Dr Din Master, Institute of Psychiatry, London.

The Laughlin Prize was awarded to Dr I. McKeith in Autumn 1981. No one was awarded the Laughlin Prize in Spring 1982.

\section{Reception of Overseas Guests}

The following overseas delegates were presented to the President: Profrssor Lesure KnOH, Royal Australian and New Zealand College of Psychiatrists; Professor CharNIE Chen, Hong Kong Psychiatric Association; DR A Zarrabi, President, Iranian Psychiatric Association; DR S. TARIQ SOHAll, Treasurer/Secretary, Pakistan Psychiatric Society; Propessor M. S. A. Gawad, President, Egyptian Psychiatric Association; DR William Sargant, Canadian Psychiatric Association.

Many other visitors from various parts of the world were also welcomed to the Meeting.

\section{Election of Honorary Fellows}

The following were unanimously welcomed to the Honorary Fellowship:

Sir Douglas Black, President of the Royal College of Physicians.

DR DAVID L. DAVIES, formerly Dean of the Institute of Psychiatry and Physician, Bethlem Royal and Maudsley Hospitals.

Professor Max Hamilton, Emeritus Professor of Psychiatry, University of Leeds School of Medicine.

Professor Robert O. Jones, formerly President of the Canadian Psychiatric Association.

Professor SIR Desmond Pond, Chief Scientist at the Department of Health and Social Security.

\section{Introduction of Honorary Fellows}

Three of the newly-elected Honorary Fellows were unable to be presented, Sir Douglas Black, Dr D. L. Davies and Professor R. O. Jones. They will receive their Honorary Fellowships at the Autumn Quarterly Meeting 1982.

Professor Max Hamilton and Professor Sir Desmond
Pond were introduced by citations as follows:

Professor Linford Rees on Professor Max Hamilton

In presenting Professor Max Hamilton, Professor Linford Rees paid tribute to his contribution to research, in particular in the field of psychometrics, where he fully utilizes his considerable mathematical and statistical skills. His most recent research activity, on rehabilitation of the chronic patient, which necessitated commuting between Leeds and New York, has provided very valuable information in this important aspect of psychiatry.

Professor Hamilton, a past-President of the British Psychological Society, was elected first President of the British Association of Psychopharmacology and was recently elected as Honorary Clinical Professor at the University of Missouri-Columbia. He is also an Honorary Professor of Psychiatry at the University of New York. He is the author of six books and many articles. His scientific achievements are indeed remarkable. These include contributions in psychometrics, mathematics and statistics, neurophysiology, the methodology of clinical trials and psychosomatic medicine, general psychiatry and psychopharmacology.

He has successfully combined scientific rigour with his warm and understanding sympathy for human suffering.

Dr W. Lumsden Walker on Professor Sir Desmond Pond

Dr Lumsden Walker, in presenting Professor Sir Desmond Pond, spoke of Sir Desmond's outstanding contribution both in the establishment and work of this College. Earlier in his career, Sir Desmond became an authority in the neurophysiology and neuropsychiatry of childhood. In particular, he was distinguished for his studies of the interaction of neurological disorder with problems of emotional and social disadvantage, and their relative importance in the epilepsies of childhood. This work remains of great value in the field of child psychiatry. He has also been an acknowledged expert lecturer and national adviser in the interface between religion and psychiatry, with expert contributions on problems of divorce and divorce law.

Dr Walker went on to speak of Sir Desmond's skill as a medical politician. During his years as our President, as a member of the Joint Consultant Committee and then as Chairman of the Conference of the Medical Royal Colleges and their Faculties, psychiatry was established as having a major voice in specialties of medicine. In this context, his charm of personality and skills in inter-personal relationships were of great value. His tenure of office as Professor of Psychiatry at the London Hospital was no less distinguished. He was well loved by his students, both undergraduate and postgraduate. Whilst those at the London Hospital must regret his retirement, Dr Lumsden Walker congratulated Sir Desmond on his recent appointment as Chief Scientist at the DHSS. His skills both as a scientist and a politician would be fully used in the hallowed portals of the DHSS. 


\section{ANNUAL DinNER}

The Annual Dinner was held at the Royal College of Obstetricians and Gynaecologists on 7 July 1982. The guests included Dr and Mrs J.D. N. Nabarro, Chairman JCC, Mr and Mrs R.M. Feroze, President of the Royal College of Obstetricians and Gynaecologists, Sir Peter and Lady Tizard, President of the British Paediatric Association, Dr Elizabeth Shore, Deputy Chief Medical Officer at the
DHSS, Lord and Lady Hunter, Professor and Mrs Max Hamilton, Professor Sir Desmond and Lady Pond, and Lord Trefgarne, Joint Parliamentary Under Secretary of State, DHSS.

The Registrar, Professor G. C. Timbury, proposed the toast of 'The Guests' and Lord Trefgarne replied and proposed the toast 'The Royal College of Psychiatrists', to which the President replied.

\section{Stop Press: The Mental Health (Amendment) Act A Sting in the Tail}

The Bill has now received Royal Assent and will be implemented in the Autumn of 1983. For a decade the College has been actively concerned with reviewing the 1959 Act and has made detailed responses to the Green Paper 1976 and to the White Paper 1978. When the Bill was introduced into the Lords in 1981 the Public Policy Committee set up a Working Party, chaired by Professor Robert Bluglass, which has laboured mightily to promote improvements in the Bill. We owe this Working Party a great debt. The Act is certainly a more acceptable and practicable piece of legislation as a result of their efforts.

There are swings and roundabouts: we applaud the establishment of a Mental Health Act Commission and we deplore the curious transmogrification of Subnormality and Severe Subnormality to Mental Impairment and Severe Mental Impairment, with its unsatisfactory redefinition of the categories. However, perhaps the most remarkable and certainly unwelcome twist was an unexpected amendment proposed by Mr Terry Davis, MP at the Report Stage in the Commons extending the requirement for a mandatory second opinion in treatments of special concern to 'patients not liable to be detained'. This means that for certain treatments in the future any patient, however willing to have the treatment (understanding its nature and confident in the doctor who proposes it), will have to be reviewed by members of an outside commission before the right to treatment is granted-and it could be refused. This amendment was, however, accepted by the Government. In the week remaining before the final debate in the Lords, the College took steps of the utmost vigour to alert their Lordships and the Government to the retrograde nature of this proposal. To saddle informal patients (or out-patients) with this onerous restriction seemed to run counter to the spirit of the 1959 Act which took steps to liberalize the standing of such patients. All to no avail. An amendment tabled in the Lords to negative this move was eloquently proposed by Lord Mottistone. Other peers agreed with him. A few were anxious lest sending the Bill back to the Commons might lead to its total failure. Nobody except the Government Minister spoke against Lord Mottistone's view. Nevertheless, when the Division bell tolled, the Government carried the day by a large majority. For the moment it will probably apply only to psychosurgery and hormone implants. For the future ...?

K. RAWNSLEY President

\section{Mr and Mrs Geaff Brooks}

After seven years as the College caretakers, Mr and Mrs Geoff Brooks retired in August this year. Staff and officers of the College and members of Council gathered together on 15 October to wish them well. Mr and Mrs Brooks write:

We wish to thank everyone who contributed towards the most acceptable and useful gifts we received on our retirement. It is gratifying to know that our services to the College were appreciated.
We have enjoyed our seven years at the College and will have some happy memories, despite the trials and tribulations that were inevitable in the reorganizing and refurbishment of the College to its present standard. Our good wishes to you all.

We welcome $\mathrm{Mr}$ and Mrs Hugh Farley as the new caretakers. 